\title{
FORTIFYING CITIZENSHIP \\ Policy Strategies for Civic Integration in \\ Western Europe
}

By SARA WALLACE GOODMAN*

\section{INTRODUCTION}

T

$\mathrm{HE}$ introduction of language and society knowledge requirements has been among the most visible if not the most significant of the policy changes for addressing the aggregate impact of mass immigration to Western Europe. Referred to collectively under the label of "civic integration," migrants are required to complete tests, courses, interviews, and so on, demonstrating language skills and knowledge as a condition for naturalization and-in several cases-settlement (obtaining permanent residence). These instruments of assessment may not seem so novel from the perspective of the United States, which has had a civics test since the 1980s and language/literacy exams for much longer. In their adoption in Europe, however, we witness the fundamental transformation of European nation-states from passive labor importers (in other words, countries that merely receive immigrants) into countries of immigration, where "the nation" is treated as a form of illiberal particularism and where immigrant-related diversity-for better or worse - assists in and serves as the catalyst for defining criteria for national membership and belonging.

It is a novel situation that Western European states require immigrants to integrate civically - to be proficient participants in the community, with commitments to liberal-democratic principles as a condition for obtaining a secure legal status in citizenship or permanent residence. Nation-states have historically maintained expectations of community membership in citizenship, extending opportunities for citizenship acquisition to ethnic émigrés or ancestry/descent-based claimants. Some

\footnotetext{
* Many thanks to Ariel Ahram, Gregory Baldi, Daniel Brunstetter, Simon Green, Marc Morjé Howard, Diana Kapiszewski, Harris Mylonas, Maarten Vink, and three anonymous reviewers for their comments.
}

World Politics 64, no. 4 (October 2012), 659-98

Copyright (C) 2012 Trustees of Princeton University doi: S0043887112000184 
even maintain civic expectations (for example, France), identifying "insiders" of the national political community by their commitment to political values and skills. But integration for "outsiders" was measured through vaguely defined "connections to the community" or a "willingness to integration," which might include language assessment in an informal interview or the completion of paperwork in the language of the host society or just duration of residence-assuming rather than assessing the integration of the applicant. Today, states use a bevy of formal instruments to measure an applicant's integration, including knowledge tests, language and civic-orientation courses, modules for role-playing society interaction, and naturalization ceremonies. This is both for acquisition of citizenship (naturalization) and for permanent residence (settlement).

To describe immigration and citizenship scholars as preoccupied with civic integration would be an understatement. In political theory, there has never been more interest in reconciling multicultural realities with liberalism. ${ }^{1}$ Among descriptive works, there have been volumes dedicated to detailing, categorizing, and comparing new policies. ${ }^{2}$ But-surprisingly — none have puzzled over the empirical diversity of civic integration policy design; nor have any presented systematic, comparative explanations for policy variation. In fact, in one account, Christian Joppke strangely dismisses this variety altogether, stating in the same breath that "despite obvious national variation in the scope and level of restrictiveness of civic integration policies across Europe, a focus on 'obligation' (and reverse de-emphasis on 'rights') is a shared feature of all of them" ${ }^{3}$ and, therefore, "the notion of national models no longer makes sense, if it ever did." ${ }^{4}$

Consistent with this observation, explanations for change have remained at the level of ideational convergence without traveling down the ladder of abstraction to take policy differentiation seriously. And they run the gamut. Looking at Joppke's work alone they include largescale demographic change, ${ }^{5}$ the general presence of an "integration crisis," indicators of "integration failure," including unemployment and

${ }^{1}$ A small sample includes Bauböck and Joppke 2010; Etzioni 2011; Joppke 2010; Kostakopoulou 2010b; Mouritsen 2006; Triadafilopoulos 2011.

${ }^{2}$ See Böcker and Strik 2011; Guild, Groenendijk, and Carrera 2009; van Oers, Ersbøll, and Kostakopoulou 2010.

${ }^{3}$ Joppke 2007a, 14.

${ }^{4}$ Joppke 2007a, 2.

${ }^{5}$ Joppke 2007b, 245-46.

${ }^{6}$ Joppke 2007b, 243. 
welfare state dependence, ${ }^{7}$ the "rightist turn of the political climate," elite consensus over the idea of civic integration, ${ }^{9}$ and shifts in the welfare state from public to private accountability. ${ }^{10}$ These explanations provide important insight into the background conditions in which change is likely to take place, but not into why states ultimately design different policy strategies. Civic integration requirements significantly vary in terms of scope (across various legal statuses), sequencing (which legal statuses are targeted first), and density (the difficulty of requirements).

Missing from these aforementioned approaches and explanations is the existing institutional context, which enables states to interpret these significant but ultimately indeterminate variables. Specifically, they do not account for inherited citizenship policy (that is, the relative ease or difficulty with which immigrants obtain citizenship) as a politically consequential structure. Not only does citizenship reflect different conceptions of inclusion, but it also summarily leads state actors to different understandings of how to perceive and repair membership problems. Existing studies consider citizenship only as a dependent variable, in order to identify the disappearance of national distinction and convergence on a basic set of liberal commitments. By contrast, an institutional approach pays attention to the role of citizenship as policy feedback: as an independent, causal variable that plays a part in producing outcomes that may replace but also reinforce it.

This article examines the institutional context in which states adopt mandatory civic integration - interchangeably referred to as membership requirements - for citizenship and permanent residence. ${ }^{11}$ In contrast to convergence accounts, I lay out a framework for identifying and understanding variation in new membership requirement strategies as a product of existing citizenship policy (the starting point) and political pressure to change it. This approach builds upon existing insights about the various means by which politics produce citizenship change, noting the agenda-setting role played by far-right parties, policy gains

${ }^{7}$ Joppke 2007a, 6 .

8 Joppke 2007a, 7.

${ }^{9}$ Joppke 2007b, 244.

${ }^{10}$ Joppke 2010, 150-51.

${ }^{11}$ This article does not include in its scope the study of integration requirements for entry. The adoption of mandatory integration for entry was driven by a distinctly separate logic than the logic driving citizenship and permanent residence and occurred in a different institutional venue. Specifically, integration-for-entry was driven by motives of admission control of family-based migration and in deliberate coordination by national elites at the European level, where the possibility of applying integration conditions was ultimately codified in EU directives. See Goodman 2011. 
through campaigns (referenda), coalition partnerships, and so on, but it also integrates an institutional perspective to highlight the different contexts in which these politics play out.

In states with restrictive (exclusive) citizenship, where opportunities to naturalize are already limited and where political actors face no pressure to break from this practice, change to membership retrenches existing citizenship postures, maintaining exclusivity of citizenship by policy designs that further disincentivize naturalization as well as expand permanent residence as an alternative membership status. By contrast, in restrictive states where there is significant pressure to liberalize, civic integration change serves as a new restriction to offset or counterbalance inclusive reforms. In both instances, where citizenship remains closed, the real focus of integration and immigrant inclusion is on permanent residence. As a more likely and - through deliberate expansions of rights - increasingly desirable category, it is expected that a migrant achieve integration during the settlement stage through dense integration programs and assessment.

In liberal (inclusive) citizenship regimes, however, states pursue fundamentally different objectives in adopting civic integration. Where citizenship orientation is politically uncontested and political actors are not required to respond to or to push against restrictive pressure, changes that introduce new membership requirements reify an existing liberal orientation, promoting an enriched citizenship by encouraging more participation and incentivizing naturalization of long-term residents. Consequently, integration for permanent residence is more connected to citizenship in liberal regimes, reducing the importance of the latter and deemphasizing differences between the two statuses. In sum, where citizenship is already accessible and immigrant integration is defined by well-entrenched policies, the challenge of membership is primarily one of achieving incorporation and defining an accessible civic identity in multicultural states. Therefore theoretical arguments for restriction are not applicable, and instead we see a variety of actorsboth across the political spectrum and in and out of power-pursuing membership requirements. Finally, liberal citizenship states that face political pressure to become more restrictive may use integration requirements to constitute that new restriction, but like restrictive regimes that face liberalizing pressure, the negotiated outcome will yield a more moderate position, avoiding costly alterations to the fundamental parameters of naturalization by producing instead a more content heavy citizenship or a more dense settlement process. 
European states face common pressures to articulate a coherent national identity in the face of immigrant-related diversity and to define avenues for inclusion for these now-permanent populations. Navigating out of membership problems may involve similar, obligatory instruments, but states use these instruments as part of different strategies to address different problems that result from citizenship policy and political pressure for change. A mandatory civics test or language course that may be restrictive in one context could enable integration in another. As a result, new requirements do not change or signal a departure from national citizenship but fortify and strengthen it. Following a detailed description and comparison of membership requirements for citizenship and permanent residence in Western Europe, I develop an institutional argument about the effects of existing citizenship policy and politics on introducing civic integration requirements. I then look at three case studies-Denmark, Germany, and the United Kingdom - to illustrate the impact of citizenship structures and politics on different strategies for promoting mandatory membership requirements. I note how respective citizenship orientations are reflected in both membership policy design (output) and implementation (outcome). Finally, the conclusion considers the instrumentalism of obligatory integration and the durability of national citizenship. It also raises a number of questions regarding the immigrant-state relationship and the overall relevance of political membership in liberal democracies.

\section{Defining Membership and Locating Requirements}

As Rogers Smith describes it, the "oldest, most basic, and most prevalent meaning [of citizenship] is a certain sort of membership in a political community." 12 Most people are born into this status and identity-encapsulated in "the nation"-but immigrants must become "insiders" through a process of naturalization (in other words, they must be "made natural"). At the same time, citizenship is also a contract whereby an immigrant-turned-citizen receives a status-including rights and membership-in exchange for duties or obligations. ${ }^{13}$ This is historically derived from periods in which a citizen would swear loyalty to a state and serve in its army in exchange for protection, rights, and mobility, but the updated version is a bit more ambiguous regarding the types of duties or obligations the citizen owes the state.

${ }^{12}$ Smith 2001, 1857.

${ }^{13}$ Tilly 1997. 
It is within this definitional framework that the introduction of mandatory civic integration - tying it to acquisition of a legal status as opposed to promoting integration for its own sake-is especially significant. It might even seem surprising that formal membership requirements were not attached to acquisition sooner, especially as some European countries are regarded as quintessential "ethnic states." In a general sense, it reveals a previous "taken for granted" quality of membership, defined in national citizenship for primarily monocultural nation-states. It also indicates a belated reaction in receiving states to large-scale demographic change, to formally articulate what was once implicit, bringing European receiving states more closely in line with traditional countries of immigration, such as the United States and Canada, by the formalization of membership. Germany and Austria especially stand out, as they had no formal language requirement before $1999 .{ }^{14}$ The Netherlands introduced an integration provision only as early as 1985 . Then, in 1998, it unveiled the Dutch Civic Integration for Newcomers program, which introduced language and society knowledge requirements for permanent residence, not simply as some vague measure of integration but as an instrument to "increase the selfsufficiency of newcomers." ${ }^{15}$ This policy became a model for other $\mathrm{Eu}-$ ropean state practices, and membership requirements promoting these skills and knowledge are now ubiquitous.

Contemporary integration requirements are far more robust than their historical counterparts and differ from them in a number of respects. First, as states have attached more rights to permanent residence (a stable legal category between temporary residence and citizenship) so have they also fostered new expectations of integration as a concomitant to this status. Thus, for example, Austria, Germany, Denmark, France, the Netherlands, and the UK all require forms of civic integration not only for citizenship but also for permanent residence. In other words, where citizenship is no longer the exclusive status establishing a permanent relationship between a person and the state, it also no longer holds the monopoly on conferring - and therefore, expectingmembership.

A second difference between traditional integration requirements and contemporary civic integration practices is in the instruments

\footnotetext{
${ }^{14}$ Germany, since the Naturalization Guidelines of 1977, did have a requirement that naturalizing foreigners demonstrate a "voluntary and lasting orientation towards Germany." This cultural assimilation test informally assessed attitude and language, with different Länder responsible for implementation. See Green 2004, 40.

${ }^{15}$ Ministry of Justice (Netherlands) 1998, 1.
} 
themselves. Today, an immigrant may be asked to achieve a standardized level of language proficiency, receive a passing mark on a countryknowledge test, complete civics education and language classes and coursework, sign or swear an oath of allegiance to the country or constitution, and/or profess a commitment to democratic values. States are adopting these requirements where there had previously been none (Austria, Denmark), while states with de jure requirements are shoring up their program with standardized assessments, moving from informal interviews and standards to formalized procedures, such as tests (Germany, the Netherlands, the UK).

Third, unlike the more historical measures of integration and in contrast to other requirements-namely, residence duration or renunciation-that qualify a person as eligible to submit an application for citizenship pro forma, obligatory integration requirements demand that the applicant take proactive, preparative measures to reach a certain level of proficiency and knowledge or declare his or her loyalty in order to complete the naturalization process. It is integration through performance and behavior, requiring active indications of commitment to naturalization, as opposed to what Peter Spiro describes as merely "being there." 16

Table 1 provides an overview of states with new integration requirements for both citizenship and permanent residence in Western Europe. It specifies (1) the nature of language and country/society knowledge assessment for citizenship and permanent residence; (2) the required level of language acquisition (according to the Common $\mathrm{Eu}-$ ropean Framework of Reference); (3) whether oaths, ceremonies, or integration contracts are required to demonstrate a commitment to a constitution, democratic values, or principles of integration; and, importantly, (4) whether requirements for citizenship can be met through fulfilling requirements for permanent residence. Years of change cover various types of reform, including initial policy adoption, raising the level of language assessment, or changing the format of the exam. The years are included not to map those specific changes but to indicate the overall recentness of new policy. Excluded from the chart are countries with no national language or country knowledge requirements (Belgium, Ireland, Italy, and Sweden), as well as states that require only language certification for citizenship (Finland, Portugal, and Spain). This latter practice, without accompanying civic integration, formalized tests, assessment of country knowledge, or mandatory courses,

${ }^{16}$ Spiro 2008. 


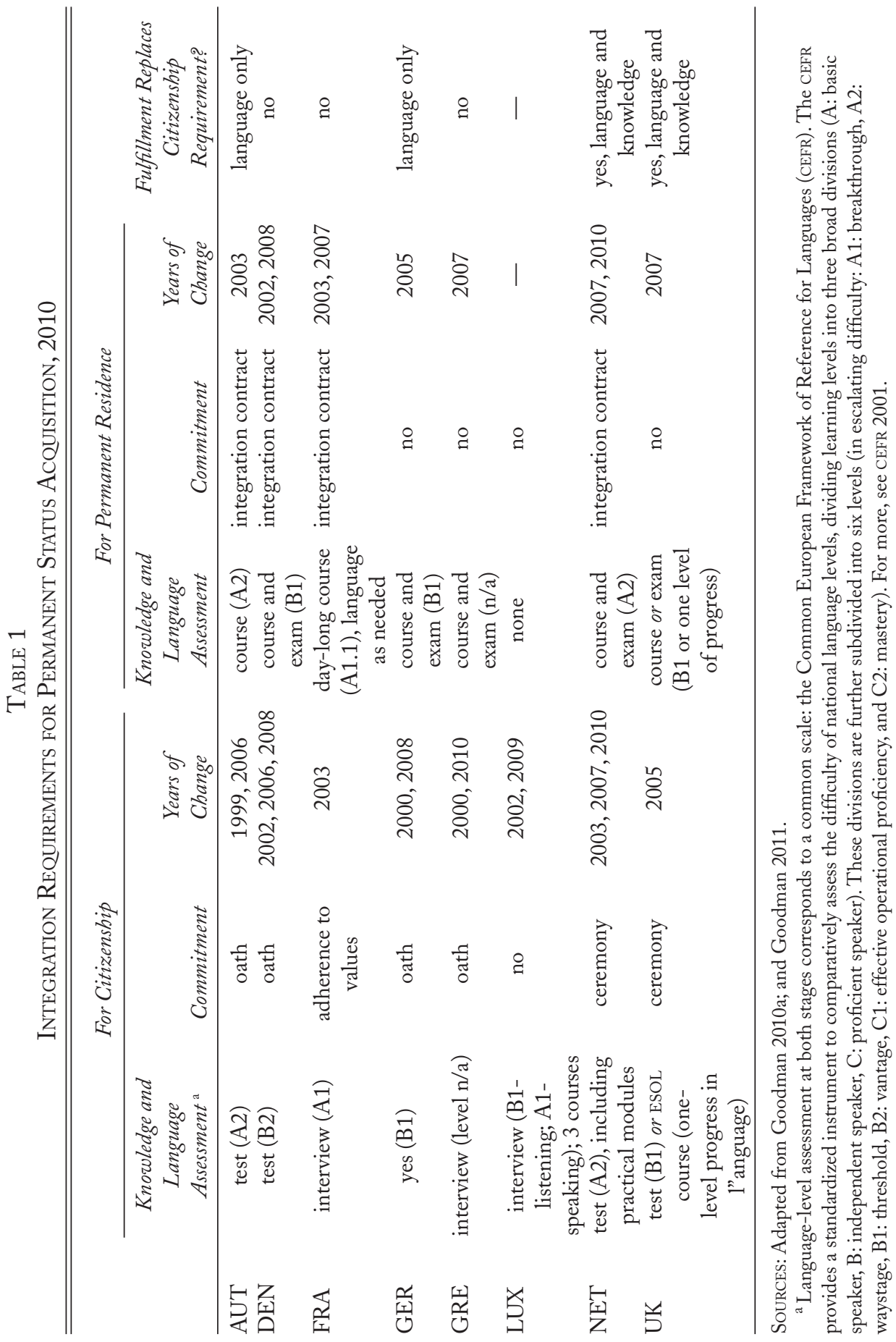


is conceptually and empirically distinct from the robust expansion of membership requirements in the past decade. In other words, these countries are not a part of the "civic turn," which is the focus of Table 1.

The "idea" of civic integration is present across these states, manifested in a variety of tests, contracts, courses, and oaths, but there are visible differences both in how difficult requirements are and in how states arrange these requirements. Austria, Denmark, and Germany emphasize civic integration for immigrants seeking permanent residence, in that it is a significant, preceding barrier of admission with integration demands. The Netherlands and the UK differ in exempting immigrants from integration for citizenship if they have completed the requirements for permanent residence (effectively removing the distinction between the two). The Dutch, it should be mentioned, employ a unique method of assessment, using a two-part exam that includes both a knowledge test on Dutch holidays, government, and customs and a practical test. For the latter test, applicants can either complete a number of "modules" that demonstrate the applicant can "use" services of society, such as finding a doctor or enrolling children in school, or they can participate in role-playing exercises. ${ }^{17}$ France is at the other end of the spectrum: the integration contract that mandates civic orientation and language for permanent residence does not have the "teeth" found in other states' requirements, and French authorities still use the interview for evaluating the "assimilation" requirement for citizenship. ${ }^{18}$ Finally, Greece passed legislation in 2010 introducing the possibility of an integration test for citizenship, but it currently continues to assess language and country knowledge through an interview.

Differences between state practices are evident not only in differences in difficulty and aggregate state arrangements but also in the sequence of policy adoption. Assuming a greater role for policy learning over time, the order in which integration policies are adopted is even more telling. In terms of mandatory integration requirements, the UK and the Netherlands comprehensively focused on citizenship (2002 and 2000, respectively) before extending requirements to permanent residence, both in 2007. Austria and Germany are cases of a reverse trend, anchoring integration conditions in permanent residence in

\footnotetext{
${ }^{17}$ There is also an "assessment route" that an applicant can take instead of the portfolio requirement; it allows candidates to role-play situations. See Strik, Luiten, and van Oers 2010.

${ }^{18}$ Effective January 1, 2012, a law was passed to require immigrants to take a test on French history, values, and language. Regarding permanent residence, instead of a test, immigrants are asked to sign a Welcome and Integration Contract, committing themselves to a one-day civic training session, French lessons, and an assessment with a social worker. For more on this, see Pascouau 2010.
} 
2002 and 2005, before replacing weak integration conditions with robust testing for citizenship in 2006 and 2007, respectively. Denmark is the quintessential case of this latter strategy. And in countries without any requirements (Ireland, Sweden, and Italy), recent proposals for language requirements have all been at the stage of citizenship exclusively. An aggregate view of policy obfuscates these important differences; sequencing of mandatory integration clearly indicates populations given top priority.

These vast differences are entirely absent from existing civic integration studies. Instead, the singular focus on ideational convergenceand consequently, relegation of policy diversity to an afterthought or minor detail of the civic integration phenomenon - has yielded a series of problematic observations that have been concretized as prima facie claims. The first is that because obligations are required by definition, they should be interpreted as synonymous with a restrictive change; that is, more requirements equal more barriers. ${ }^{19}$ Viewed from this theoretical vantage, integration requirements have been interpreted as representing an "illiberal liberalism" 20 that constitutes a "restrictive turn" or "backlash" against the vast liberalization of citizenship policies in the 1990s, policies that included the widening acceptance of dual citizenship and the lowering of residence duration. ${ }^{21}$ But these approaches are limiting because (1) if any requirement is considered restrictive, then the bar of acceptable requirements the state can ask of a newcomer is essentially set at zero, which betrays the widely accepted notion of citizenship as an exchange of rights from the state for obligations by the citizen; and (2) language and society knowledge tests can actually enable integration and produce inclusion, not exclusion. ${ }^{22}$ Overreliance on this blunt characterization tool diverts attention from what is happening on the ground.

The second problematic claim is that civic integration is the same phenomenon in every state. The premise that civic integration policy is one idea sweeping across European states obscures the very obvious empirical differences in policy difficulty, sequencing, and scope. In fact, the preoccupation with ideational convergence and the resulting diminution of national variation have led to significant scholarly disagree-

\footnotetext{
${ }^{19}$ For examples of this usage, see Howard 2009; Joppke 2007a; Koopmans et al. 2005; Migration Policy Group 2011; and Ryan 2008.

${ }^{20}$ Guild et al. 2009; Joppke 2007a; Orgad 2010; Triadafilopoulous 2011.

${ }^{21}$ For more on this "backlash" or the return of assimilation, see Brubaker 2001; Joppke 2004; Joppke 2008; and Joppke and Morawska 2003.

${ }^{22}$ See Hansen 2008a.
} 
ment over the significance of new policy in the absence of a parallel discussion of initial causes. One camp interprets integration requirements as representing a move away from the nation ${ }^{23}$ while the other sees the promotion of language and society knowledge as a return to it. ${ }^{24} \mathrm{I}$ submit that this disjuncture is more of a reflection of differences between civic integration policies than existing studies acknowledge or take seriously.

Finally, and related to this view of uniform convergence, there is a third problematic claim: that "distinct national models of dealing with immigrants are giving way to convergent policies of civic integration." 25 This view of convergence is predicated on the idea that similar instruments produce similar outcomes, even going so far as to posit that they were adopted for similar macroreasons. Change is seen as part of a larger, comprehensive strategy of major immigrant-receiving states for addressing the demographic shifts and diversity-related pressures of immigration. But if a mandatory membership strategy is a response to large-scale immigration, why do states make changes at the stage of citizenship if other requirements for naturalization make it so that only a tiny percentage of foreign residents will be able to obtain it? And, in countries where immigrants are more likely to obtain citizenship and have higher rates of naturalization over time, why do policy actors perceive of membership problems at this time? Given the constant but indeterminate pressures of immigration and demographic change- $-\mathrm{a}$ necessary but insufficient explanation for policy change- the next section examines how states interpret different membership problems as a result of existing citizenship orientations and politics.

\section{Citizenship Policy Orientations and the Role of Politics}

As previously stated, among the numerous studies that examine civic integration specifically, there have not been comparative studies of initial conditions that may have led states to adopt membership change, much less studies that even acknowledge the diversity of membership requirements as a serious or significant sign of variation. I draw on the approach of historical institutionalism for interpreting how citi-

\footnotetext{
${ }^{23}$ Joppke 2010; Müller 2007; Orgad 2010. 2008.

${ }^{24}$ Jacobs and Rea 2007; Mouritsen 2011; van Oers, Ersbøll, and Kostakopoulou 2010; Wright

${ }^{25}$ Joppke 2007b, 243. Here, Joppke is making a direct reference to models of integration (multiculturalism, assimilation, and segregationism). The oversight of citizenship in his framework is surprising: requirements may impact integration policy (they may also promote inclusion or closure) but they definitely affect the acquisition of secure legal status.
} 
zenship fits into the analysis to mediate immigrant-related pressures and contextualize politics. This framework of analysis recognizes how "organizational factors affect both the degree of pressure an actor can bring to bear on policy and the likely direction of that pressure." ${ }^{26}$ Specifically, the article draws on the strand of historical institutionalism that focuses on path dependence and the role of inherited policies in shaping politics. As Paul Pierson notes, public policies, like formal institutions, are "not only outputs of but important inputs into the political process, often dramatically reshaping social, economic, and political conditions." 27

Citizenship is defined by a set of policies that confers status, rights, and identity upon its holder. In that regard, it has been described as demarking both a territorial community and a membership association. ${ }^{28}$ If one is not born into the desired citizenship, the process of acquiring citizenship is defined by successful passage through a series of barriers that make acquisition relatively easy or hard, depending on the receiving state's conception of membership. ${ }^{29}$ And we can look at citizenship policies - the rules that make it more or less difficult to acquire citizenship - as reflections of state understandings of membership. As Randall Hansen and Patrick Weil succinctly note, rules for citizenship acquisition can be interpreted as giving formal, "institutional expression to the state's prerogative of inclusion and exclusion." ${ }^{30}$

Along these lines, states were originally grouped into dichotomous categories based on nationalism tropes. "Civic" states were considered inclusive and "ethnic" states were exclusive. ${ }^{31}$ More recently, scholars have moved beyond these descriptions to more graded approaches to citizenship, where states can boast dynamic configurations of citizenship policies that add up to restrictive or liberal orientations. ${ }^{32}$ States are categorized as having a liberal or inclusive policy orientation where there are shorter periods of residence, allowance for dual citizenship, and acquisition through birth in a territory (jus soli). By contrast, states are considered as having a restrictive or exclusive policy orientation

${ }^{26}$ Hall 1986, 19.

${ }^{27}$ Pierson 1993, 595.

${ }^{28}$ Brubaker 1992; Joppke 1999.

${ }^{29}$ Citizenship for outsiders can sometimes be acquired at birth (jus soli confers citizenship by birth in a territory to the child of noncitizen parents), while after birth typically requires a process of naturalization, declaration, or registration for adults and minors.

${ }^{30}$ Hansen and Weil 2001, 1.

${ }^{31}$ See Brubaker 1992; Castles and Miller 2003; Koopmans et al. 2005.

${ }^{32}$ See Howard 2009; Janoski 2010; Migration Policy Group 2011. This move from dichotomous citizenship identities not only reflects empirical complexity in policy configurations but is also consistent with empirical studies that identify overlaps in identity, such as Reeskens and Hooghe 2010. 
where longer periods of residence are required, immigrants must renounce other citizenships, and children born of immigrants in the host country are excluded from citizenship. ${ }^{33}$

Citizenship also has a distinct but misunderstood impact on permanent residence. Postnationalist theorists in the 1990s saw a diminished role for national citizenship because more and more rights, from social assistance to local voting, were linked to permanent residence. ${ }^{34}$ This view positioned the rise of permanent residence in a zero-sum relationship with the decline of citizenship as a rights generator, leaving national citizenship's chief relevance as the conferral of membership. But the connection between these two statuses is mutually constitutive. In the context of large-scale migrant populations, permanent residence matters precisely where citizenship is unobtainable, namely, because of renunciation requirements prohibiting dual citizenship (Austria, Denmark, Germany) or nongranting for second- or third-generation migrants born in the country (Austria, Denmark, Finland, Greece, Italy, Luxembourg). Where citizenship is difficult to obtain, immigrantrelated integration policies are strongly tied to permanent residence (settlement) procedures. States can use permanent residence as a strategic alternative to inclusion in national citizenship (creating a type of demicitizenship). Where citizenship is relatively easy to obtain, permanent residence is of less importance. Or the concern for citizenship is even starker if migrants show a preference for permanent residence over citizenship in these more inclusive settings.

The central role of citizenship in defining membership, legal status, and inclusion endures despite postnational and transnational predictions. ${ }^{35}$ But while citizenship, like many formal institutions, is typically described by its continuity over time, it is also a set of policies that has proved to be dynamic. In fact, changes to citizenship requirements have dominated the European policy arena in the past few decades as states have sought to reconcile monocultural pasts with multicultural realities. This has manifested itself in restrictive countries becoming more liberal (Finland, Luxembourg, Portugal, and Sweden) and in moves or provocations toward greater restriction in others (Belgium, France, the

${ }^{33}$ These policy indicators are derived from Howard 2009. There are obviously numerous other policies that matter for citizenship acquisition, but high correlations between the many indices of citizenship (reported in Koopmans et al. 2012) suggest that picking a few key indicators is sufficiently representative. For more in-depth comparisons of these and other naturalization policies, including administrative fees, health and criminal record requirements, and so on, see Goodman 2010b. For a detailed comparison of jus soli policy, see Vink and de Groot 2010.

34 Soysal 1994; Jacobson 1997; Sassen 1998.

${ }^{35}$ See Hansen's (2008b) critique and defense of a "reinvigorated citizenship." 
Netherlands, and the UK). Citizenship scholars have pointed out the large role politics plays in accounting for this change. Christian Joppke looks at right-of-center governments for the "re-ethnicization" of policy, ${ }^{36}$ whereas Martin Schain and Marc Morjé Howard both examine the role of far-right political parties in fostering policy changes toward more restrictive citizenship or blocking liberalization, respectively. ${ }^{37}$ However, there are some limitations in taking an exclusive, politicsoriented approach. For example, a focus on parties in power overlooks the real actors who produce membership requirements. In Germany, Austria, and the Netherlands, the right-of-center or far-right party operates from opposition to broker new civic integration requirements. And the UK is a perpetual outlier in a politically grounded analysis, because there is an absence of significant far-right parties, a majoritarian system that does not foster a role for veto players, and the presence of a center-left government for over a decade.

Civic integration requirements are part and parcel of this politically altered landscape, and introducing an institutional perspective that examines inherited citizenship policy orientation as a starting point contextualizes this otherwise indeterminate political activity. As Pierson notes, "individuals choose, but the conditions that frame their decision provide strong inducements to make particular choices." 38 Taking a dynamic view, the particular inherited legacy of citizenship policy determines the starting point for policy continuity or change, and politics shapes the likelihood for it, recognizing that "institutions constrain and refract politics but they are never the sole 'cause' of outcomes." ${ }^{39}$ In this institutional context, politics can contribute to either positive or negative feedback cycles. We see civic requirements deriving from an incremental process associated with a variety of political activities, including agenda setting by a far-right party, coalition bargaining, oppositional pressure, and policy entrepreneurs. Political actors can most successfully reinforce or change citizenship orientation from a position of power, that is, from within the government or coalition. But, in the language of institutionalism, change over continuity is more "costly," especially when actors operate within the short time horizon of elections. Where change is successfully challenged by opposing actors, future attempts at change will show political "learning effects" and be less ambitious in scope. In sum, politics can produce change, but dynamics

\footnotetext{
${ }^{36}$ Joppke 2003.

${ }^{37}$ Schain 2008; Howard 2009.

${ }^{38}$ Pierson 1993, 598.

${ }^{39}$ Thelen and Steinmo 1992, 3.
} 
suggest it is harder won in the short term as parties are checked by competition. The cumulative effects of change across electoral cycles may weigh more heavily on altering the orientation of citizenship over time, but in the immediate time horizon, politics mediated by policy structures plays a key role in the self-reinforcing activity of citizenship policy orientation.

Therefore, finding answers to the research question-how do states use civic integration? - requires looking both at institutional starting points (citizenship orientation) and at the pressures to change them. Figure 1 presents an empirical typology for examining the different civic integration strategies that result from the presence or absence of citizenship politics in liberal and restrictive policy settings. Included in parentheses are the selected case studies of the present article. ${ }^{40}$

In restrictive citizenship policy regimes, opportunities to naturalize are already limited. Pushes for membership requirements in the absence of liberalizing pressure (category 1 ) further retrench the difficulty of obtaining citizenship, improving the distinction between insider and outsider by disincentivizing naturalization and expanding the importance of permanent residence. Where there is significant political pressure to alter citizenship (category 2) by governments pushing for liberalization or by far- and center-right parties pushing against it, the result is likely to be negotiated and more intermediate, where exclusive citizenship is maintained but moderated. In both cases, mandatory integration requirements are most pronounced at the stage of permanent residence, creating a path whereby a migrant can achieve civic integration independent of the traditional civic status.

In liberal citizenship regimes, however, political actors who pursue integration requirements operate within a different set of constraints. Absent political pressure for restriction (category 3), membership requirements aim to promote, not deter, national citizenship uptake. Requirements address problems of cohesion and serve to enrich citizenship by encouraging more participation and to incentivize naturalization. And where governments face restrictive pressure (category 4), by minority parties or a mobilized public, for example, mandatory integration requirements can constitute new barriers, but like restrictive states with liberalizing pressure, they are negotiated and more moderate. For example, permanent residence may become more strategically

\footnotetext{
${ }^{40}$ These embedded case study references are meant to guide and orient the reader, not to represent an exhaustive list. For example, Austria might be included in category 1, while the Netherlands would be a quintessential representation of category 4 .
} 
Political Pressure to Change Citizenship

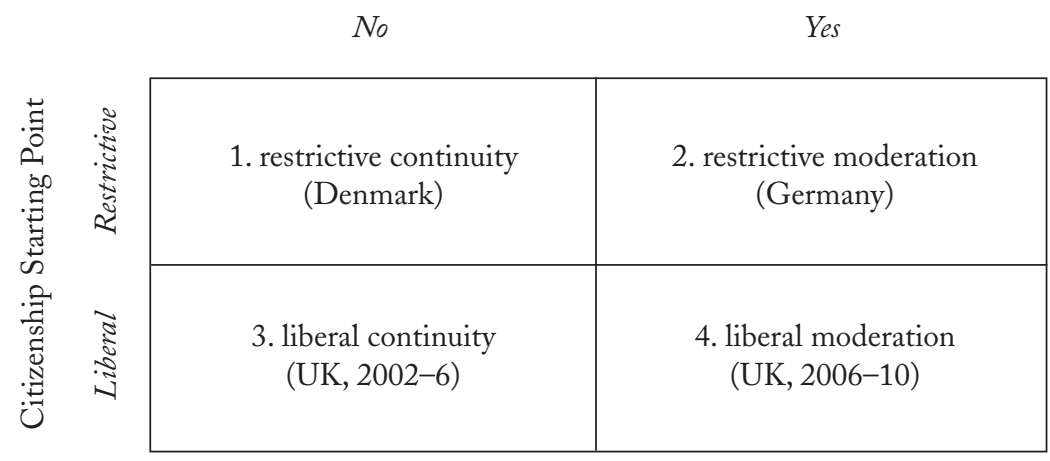

FiguRe 1

Diversity in Civic Integration Policy Strategy

prominent as an alternative to or an antechamber for citizenship, allowing citizenship itself to remain liberal. ${ }^{41}$

In sum, mandatory integration requirements reinforce instead of replace the major contours of citizenship policy and the membership association it maintains. In all cases, requirements add new content to citizenship, defining in an explicit way - for the first time-what it means to be Danish, German, Dutch, British, and so on for statusseeking immigrants. But we see that existing institutional configurations mediate different strategies for how states promote these new definitions, particularly in terms of how policymakers design civic integration to capitalize on the dovetailing dimensions of citizenship and permanent residence. The next section presents three case studies to illustrate the different strategic uses of civic integration requirements in the context of varying institutional start points and political pressure. The cases of Denmark, Germany, and the UK show the variety of strategies to address membership problems resulting from large-scale migration, with each using civic integration ideas but for different purposes and in different settings. An exemplary case of retrenchment is Denmark, where membership requirements for citizenship strengthen existing closure and raised requirements for permanent residence create a stable demicitizenship as an alternative to national citizenship, achieved in the absence of oppositional political pressure. Germany

\footnotetext{
${ }^{41}$ Oftentimes, recent restrictions in liberal settings amount to a type of normalization of aberrant liberal practices. See Goodman and Howard 2011.
} 
is a case of moderate restriction, where civic integration requirements were produced by a series of bargained compromises, first as a concession to the right of center in exchange for significant liberalization in the 2000 Citizenship Act and later in response to right-leaning state interpretations of federal law. Finally, the UK case demonstrates both the adoption of integration requirements to promote and maintain liberal citizenship and the attempt to instrumentalize integration requirements as a means of restriction in response to pressure for immigration control. I present evidence that illustrates not only how design differences in the membership requirement-that is, policy output-are consistent with variation in citizenship orientation but also how this variation is reinforced in different outcomes consistent with initial policy legacies, measured in test pass rates and acquisition data.

\section{DenMark: Restrictive Continuity}

Denmark has become a state of distinct contrasts as a result of immigration. On the one hand, it is "known as a liberal Scandinavian country, tolerant towards alternative lifestyles" ${ }^{42}$ where "equality and individual autonomy are often interpreted as valuable ways of life ... [and] the welfare state is the institutional carrier of this modern project of liberation." ${ }^{43}$ On the other hand, it "remains ethnocultural in terms of membership and an instrumental pursuit of cohesion-as-homogeneity." 44

This delicate (im)balance is maintained in both citizenship and permanent residence policy. As citizenship policy has moved from "moderately restrictive to very restrictive," 45 the focus on the content and utility of permanent residence has grown exponentially. Indeed, dense integration requirements for permanent residence have front-loaded integration expectations so that Danish citizenship was "something to strive for, an incentive for foreigners to adapt to Danish society." ${ }^{46}$ Naturalization is not an instrument for integration as in some countries (for example, Sweden) but a reward. And for some immigrants, integration requirements "serve as civic-screening and exclusion devices: some people just cannot and should not become members." 47

\footnotetext{
${ }^{42}$ Mouritsen and Olsen 2011, 1.

${ }^{43}$ Mouritsen 2006, 86.

${ }^{44}$ Mouritsen and Olsen 2011, 3.

${ }^{45}$ Ersbøll 2010, 107.

${ }^{46}$ Ersbøll 2010, 133.

${ }^{47}$ Mouritsen and Olsen 2011, 8.
} 
Policy change that maintains Danish citizenship as an out-of-reach reward and permanent residence as a dense, integration experience exemplifies restrictive citizenship continuity through retrenchment (category 1). Citizenship is preserved as a mechanism of exclusion, not only by introducing new requirements in an attempt to reduce the number of naturalizations but also by expanding permanent residence as an alternative status of identity and rights. This strategy can largely be attributed to the political agenda of the Danish People's Party, which supported the government coalition and lobbied for closure in a political atmosphere conducive to far-right concessions.

In the late 1990s, Danish citizenship law was among the most restrictive in Europe, reflecting its monocultural roots by denying allowances for dual citizenship or acquisition through jus soli, as well as by maintaining a seven-year residence requirement. It also had a long-standing language requirement (dating from 1849) that included an informal assessment of speaking and understanding Danish by "the (local) police during its preparation of cases for naturalization." 48 In 1999, however, the state indicated its first priority for integration not at the stage of citizenship but at the stage of permanent residence by introducing the Integration Act. Claiming to be the "the first country in the world" to do so, ${ }^{49}$ the state began to provide free introductory courses on language and society knowledge for immigrants for the first three years of their settlement (after which time they qualified for permanent residence). This was only the first brick in what was to become an expansive integration structure anchored in permanent residence.

Immigrants had been coming to Denmark for decades, but Per Mouritsen and Tore Vincents Olsen characterize the period of the late 1990s as distinct because of the "high political saliency of the immigrant question and by the notion that immigrants must be induced to acquire the 'fundamental values' of Danish society." ${ }^{50}$ In this context, the far-right Danish People's Party, which was "hostile towards cultural pluralism ... [and wishing] to preserve the nation as vessel of majority belonging," 51 was able to add new restrictions to the existing ones from inside government. Bolstered by their successful, third-place finish (12 percent of the national vote) in the 2001 parliamentary elections, which catapulted them into coalition partnership in the Liberal-Conservative

\footnotetext{
${ }^{48}$ Ersbøll and Gravesen 2010, 57.

${ }^{49}$ Ministry of Refugee, Immigration, and Integration Affairs Web site (Denmark) 2011.

${ }^{50}$ Mouritsen and Olsen 2011, 3.

${ }^{51}$ Mouritsen 2006, 71-72.
} 
minority government, incremental restrictions were added by means of the political agreement.

The 2002 Government Agreement on Citizenship therefore introduced a new requirement, that immigrants document their language ability for citizenship with either a test or schooling. The new agreement also raised the duration of residence (from seven to nine years), maintained the resistance to dual citizenship, tightened the conduct requirement, repealed an exemption for elderly applicants (sixty-five and over) from the language requirement, ${ }^{52}$ and introduced a declaration of faithfulness and loyalty to Denmark..$^{53}$ These new restrictions were heavily influenced by far-right pressure, but they were also introduced in a political environment more generally conducive to continued restriction. As Eva Ersbøll notes, "in the 1990s, while the Social Democrats were in power, some moves were afoot among the opposition parties for extending the language requirement for naturalization." ${ }^{44}$ She goes on to comment that Liberals, Conservatives, the Progress Party (Denmark's first anti-immigrant party), and later the Danish People's Party all had similar proposals for testing, reading, and writing abilities.

After the 2005 election, the DPP continued using its governmentsupporting position to restrict citizenship. New restrictions for citizenship included raising the level of language proficiency (from B1 to B2), introducing a citizenship test on Danish culture, history, and society, and eventually raising the standards and difficulty of the citizenship test. Since the DPP has continued to serve as "the government's safety net" following the 2001, 2005, and 2007 elections, ${ }^{55}$ the party has used its strategic position to introduce incremental restrictions for both citizenship and permanent residence.

On top of making citizenship more exclusive, a second restrictive strategy entailed increasing the distinction between citizens and immigrants by emphasizing the importance and instrumentality of permanent residence. Through successive reforms to the 1999 Act (in 2005 and 2010), the DPP was a key driver in making integration a cornerstone of acquiring permanent residence, including but not limited to (1) an integration contract including personal assessment; (2) active

\footnotetext{
52 This is just one of many examples of Denmark's unique omission of exemptions, rendering permanent residence and citizenship acquisition comparatively difficult for at-risk or vulnerable populations. See Ersbøll and Gravesen 2010.

${ }^{53}$ Ersbøll 2010, 133-34.

${ }^{54}$ Ersbøll 2010, 133.

${ }^{55}$ Ersbøll 2010, 138.
} 
citizenship demonstrated in taking a test or participation; (3) language acquisition or full employment; (4) a declaration on integration and active citizenship; and (5) an extended residency period (from three to seven years). It is a process that both builds skills and civic identity among immigrants and makes the acquisition of permanent residence more difficult. The incongruity should not be missed: immigrants are asked to adapt to Danish society through the practice of "active citizenship" without actually becoming Danish citizens.

This strong link between settlement and civic integration serves two purposes: functional integration and effective closure. There are real benefits reaped by immigrants in completing integration during settlement, specifically in terms of obtaining skills for gaining access to the labor market. ${ }^{56}$ However, alongside this function, the exclusionary objectives are palpable. On the one hand, promoting dense membership criteria for settlement offers further confirmation that "the government does not consider citizenship a 'must' for immigrants. ${ }^{\text {" } 77}$ On the other hand, it becomes "more difficult for immigrants who are 'not well integrated' to obtain permanent residence." 58

In exercising quintessential retrenchment, Denmark shows how states can use civic integration requirements to reduce access to citizenship, as well as to distinguish an identity for citizenship from an identity for long-term residents. Turning from policy output to outcome, we can note a distinct decline in acquisition of both permanent residence and citizenship..$^{59}$ First, in Table 2, we see the total number of applications for permanent residence granted and denied between 2003 and 2009. Language and integration, in addition to factors like lengthy residence and employment requirements, drive the downward trend. There is a steep incline in both the rate of refusal and the number of applications made in the first place. In this, not only are new requirements an exclusionary barrier, but they also serve as a disincentivizing selection mechanism for immigrants to apply at earlier barriers like entry and reunification. The controversial points system for family reunification, for example, consisting of language skills, work require-

${ }^{56}$ See participant interviews in Ersbøll and Gravesen 2010.

${ }^{57}$ Ersbøll 2010, 139.

${ }^{58}$ Böcker and Strik 2011, 167.

${ }^{59}$ There are data limitations in examining integration requirements directly, as Ersbøll and Gravesen 2010 note: "Virtually no literature or public statistics exist on the effects of the test" at permanent residence and "due to the general residence requirement of 7 years (introduced in 2002), the full effects of the integration examination had not been seen (or evaluted) before the new and even more restrictive requirements were introduced in 2010" (pp. 32-34). For this reason, I examine application trends for this legal stage. 
TABLE 2

Applications for Permanent Residence in Denmark, 2003-9

\begin{tabular}{lccccccc}
\hline \hline & 2003 & 2004 & 2005 & 2006 & 2007 & 2008 & 2009 \\
\hline Total Number of & 9360 & 10738 & 9161 & 3641 & 1788 & 3058 & 2726 \\
$\quad$ Permits Issued & & & & & & & \\
Total of Refusals & 2276 & 2316 & 2260 & 2238 & 966 & 2349 & 1786 \\
Total of Decisions & 11636 & 13054 & 11431 & 5879 & 2754 & 5407 & 4512 \\
Percentage of & 19.6 & 17.7 & 19.8 & 38.1 & 35.1 & 43.4 & 39.6 \\
$\quad$ Refusals & & & & & & & \\
\hline
\end{tabular}

SourcE: Ersbøll and Gravesen 2010, 33.

ment, community service, and other criteria, is so strict that the number of resident permit approvals fell by 70 percent. $^{60}$

We can further see the direct impact of integration requirements at the stage of citizenship. The requirement of passing a naturalization test produced 1016 refusals in 2008, or 12 percent of total refusals. ${ }^{61}$ The language proficiency requirement has produced some even more exclusionary results. Table 3 presents percentages of applicants refused citizenship between 2001 and 2008 on the grounds of lack of language proficiency. While figures vary across the year, we see that language is a significant barrier to acquisition; about half of all rejections result from failure to meet the language requirement. This is one of many significant tributaries driving down naturalization, from 2.5 percent of the foreign population in 2000 to 1.4 percent in $2008 .^{62}$

While promoting real skill and incorporation among a segment of immigrants (those capable of running the dense requirement gauntlet), civic requirements in Denmark serve to strengthen an exclusive national membership community in the absence of liberalizing pressure. Against ideational convergence accounts, especially those that see new requirements signifying proimmigrant and postnational positions, the adoption and implementation of new policies reflects continued restriction and national retrenchment. As Mouritsen points out, the "mere existence of civic ideals as conditions of belonging is no guarantee of a non-exclusive discourse," which reflects an "unwillingness to enter public interpretations about reasonable plural meanings" of Danish culture. ${ }^{63}$

\footnotetext{
${ }^{60}$ Buley 2012.

${ }^{61}$ Ersbøll and Gravesen 2010, 65.

${ }^{62}$ OECD 2010.

${ }^{63}$ Mouritsen 2006, 88.
} 
TABLE 3

Refusals of Naturalization due to Lack of Danish Language Proficiency, 2001-8

\begin{tabular}{lcccccccc}
\hline \hline & 2001 & 2002 & 2003 & 2004 & 2005 & 2006 & 2007 & 2008 \\
\hline $\begin{array}{l}\text { Number of } \\
\begin{array}{l}\text { Persons } \\
\text { Percentage }\end{array}\end{array}$ & 778 & 503 & 2507 & 1632 & 1185 & 961 & 1498 & 3446 \\
\hline
\end{tabular}

SOURCE: Ersbøll and Gravesen 2010, 66.

\section{Germany: Moderated Restriction}

Germany is similar to Denmark in that right-of-center parties have strengthened the content of citizenship through new requirements and through investment in permanent residence in a restrictive citizenship context. But a crucial difference between these two cases is the role of politics in producing new restrictions. Integration requirements for citizenship and permanent residence were not "concessions" given to a needed coalition partner in a political climate leaning toward restrictions, but instead they were a set of domestic policies "won" through careful politics, mobilizing public opinion, and making use of Germany's federal system, where right-leaning states are legally empowered to develop their own policies independent of the federal government. Indeed, efforts to liberalize citizenship early on in the Social Democrats (SPD)-Green coalition were successfully tempered by an effective opposition, setting the tone for future change. The outcome is restriction through negotiation, an ultimately more moderate civic integration strategy than cases of uncontested retrenchment (category 2).

The introduction of membership requirements for citizenship in Germany immediately signals the "taken for granted" nature of citizenship as a membership association. Germany was often touted as the quintessential "ethnic" model of citizenship in Europe, basing citizenship on the principle of jus sanguinis, or citizenship by parentage. The federal state had successfully maintained this reputation through restrictive rules for citizenship acquisition in the context of large-scale immigration over time until the 2000 Citizenship Law, which lowered the residency duration from fifteen to eight years and introduced a type of jus soli for children of nonnational permanent residents. ${ }^{64} \mathrm{It}$ was as a concomitant of this liberalization that a formal integration

\footnotetext{
${ }^{64}$ Some scholars question the extent to which this liberalization is anything more than lip service. See Green 2012; Schönwälder and Triadafilopoulos 2012.
} 
requirement first appeared for citizenship. The new law required proof of integration to be assessed through "sufficient oral and written German language skills," instead of inferred by demonstrating a "voluntary and lasting orientation." As the federal government did not articulate a standardized assessment level or instrument for German proficiency, the Länder authorities had substantial discretion. This led to varying practices across Germany, ranging from oral interviews to written exams. The 2000 Law also implemented a requirement of a declaration of loyalty - specifically a "commitment to democratic order and constitution." 65

The significant liberalization of the 2000 Law was passed as one of the first priorities of the newly elected SPD-Green coalition, replacing the longtime conservative coalition in the 1998 election. There were two clear objectives to the liberalization of citizenship: (1) increase the number of naturalizations of permanent residents; and (2) improve the integration of immigrants and their German-born children through citizenship. ${ }^{66}$ It also took place in the context of a decade of incremental increase in citizenship acquisition, whereby naturalization rose slowly from 1.02 percent in 1995 to almost 2 percent in $1999 .{ }^{67}$ This did not signal increased opportunities for citizenship as much as it did increased demand.

This agenda created anxiety among the center right, specifically the unseated coalition of Christian Democrats (CDU) and their Bavarian sister party Christian Social Union (CSU). Through an unprecedented petition campaign and regional elections in Hesse that shifted the balance in the Bundesrat, these center-right actors were able to block the introduction of dual citizenship. ${ }^{68}$ And, at the cost of the aforementioned liberalization that did go through, the citizenship bill carried with it the first round of what Helen Hartnell describes as an "integration price tag," namely, the language requirement and oath. ${ }^{69}$ In fact, the CDU/CSU ultimately opposed the citizenship bill in the Bundestag for not requiring enough integration, wanting to require knowledge of constitutional order alongside language in exchange for other conces-

\footnotetext{
${ }^{65}$ Green 2012 notes that this oath was strategically included to have legal grounds to exclude "those applicants from citizenship in which concrete suspicions [ ] cast doubt on their willingness to conform to Germany's constitutional order [ ] - a provision targeted at applicants with extremist political tendencies" (p. 176).

${ }^{66}$ These distinctions are made by van Oers 2010, 71 .

${ }^{67}$ OECD 2003.

${ }^{68}$ In the end, the government created a type of temporary dual citizenship, where a person holds dual citizenship automatically at birth but is required to give one of the two up by age twenty-three.

${ }^{69}$ Hartnell 2006, 391.
} 
sions of liberalization. ${ }^{70}$ During parliamentary debate over the bill, $\mathrm{CDU} / \mathrm{CSU}$ politicians decried the liberalizing reforms as giving away "naturalization for free."

The addition of membership requirements for citizenship through politics is further evident in the 2008 adoption of a citizenship test to assess "knowledge of the legal and social system and the way of life in the Federal territory." And the conservatively governed Länder of Baden-Württemberg and Hesse introduced state-level tests focusing on assimilation in 2005-6. The former was referred to as a "Muslim test" because it asked leading questions for a specific profile. For example: "Shall a woman be permitted to be alone in public or to go on holiday on her own - what is your opinion about that?"72 These independent state practices led to a meeting of CDU/CSU interior ministers that called for a national values test, which then led to a recommendation for a federal-level test by the Conference of Senators and Ministers of Interiors (IMK), produced as a compromise to prevent further individual practices.

Part and parcel of this counterbalancing by the right-of-center parties at the stage of citizenship is civic integration, which has also importantly expanded into a comprehensive immigrant integration strategy for permanent residence. Dating back to the 1990 Aliens Act, which first introduced language as a requirement for permanent residence, permanent residence has always been and continues to be the heart of the integration agenda. The importance of language courses and tests was considerably expanded in 2004 with the Immigration Act. Here, we also see restrictive interests playing a role in offsetting liberalizing pressures to produce, in the end, a moderate compromise. The Süssmuth Commission, set up by the SPD-Green government in 1999, proposed in its 2001 report the creation of integration programs for immigrants. The commission's purpose in setting integration requirements was to target poor language skills as an impediment to accessing the labor market and political participation. However, that sanctions were eventually tied to this program - namely, withholding a permanent residence permit or possibly reducing welfare benefits (similar to Denmark) — can be attributed to "political entrepreneurs and parties ... who were opposed to the more liberal ideas put forward by the Süssmuth Commission." 73

\footnotetext{
${ }^{70}$ Van Oers 2010, 72-73.

${ }^{71}$ Van Oers 2010, 72.

${ }^{72}$ De Groot et al. 2009, 60.

${ }^{73}$ Michalowski 2010, 188.
} 
According to the 2002 Coalition Agreement, requirements at the stage of permanent residence were a way to "promote and also demand the integration of immigrants." 74 Requirements have evolved to include participation in an integration course of (at most) nine hundred units of language courses and forty-five units of civic orientation, and culminating in both language and civics tests. In contrast to Denmark, permanent residence is slightly more connected to citizenship in that migrants earn a reprieve from the language requirement for citizenship if they complete it for permanent residence. A migrant with sufficient German (defined at or above the B1 level) also does not need to complete the language course and may produce certification of proficiency instead of sitting for the standardized exam. ${ }^{75}$ Finally, a migrant can also obtain a one-year residency reduction toward citizenship if he or she completes the integration criteria prescribed for permanent residence. Course fees vary between $€ 645$ and $€ 945$ ( $\$ 797$ and \$1168), with possible rebates for the unemployed, those receiving social assistance, or those who achieve timely completion. In this design, we see a moderated restrictive outcome design: barriers are high for those with insufficient ability (the B1 level for permanent residence is the same level asked for citizenship), but there are avenues that allow for acceleration.

In shifting from output to outcome, while there is a minimal effect of civic integration requirements on citizenship acquisition-owing in large part to its negotiated origins-we see that language and country knowledge requirements successfully work to preserve an unequivocal shade of restriction in permanent residence. Preempting the filtering power once the preserve of citizenship, permanent residence has been structured to be a consequential, prohibitive barrier to "promote and also demand" integration. Table 4 shows startlingly lower pass rates of the language test among candidates for permanent residence than among those for citizenship. It also shows that before the 2007 reforms to the integration program, integration course graduates were performing far worse on the language exam than those who did not complete the course. These figures have since been improved, and as recently as 2009 , two-thirds of course graduates were passing the language exam at the B1 level.

These figures are far below the citizenship pass rate (at 98.9 percent), ${ }^{76}$ leaving a large segment of immigrants in need of more language

${ }^{74}$ Seveker and Walter 2010.

${ }^{75}$ The migrant is still required to attend the civic orientation component of the integration course and, since 2009, take the culminating exam, unless he or she has certification of having completed German secondary school (Seveker and Walter 2010).

${ }^{76}$ Spiegel Online 2009. 
TABLE 4

Pass Rates for Integration Course and Language Requirement for Permanent Residence in Germany, 2005-9

\begin{tabular}{lccccc}
\hline \hline & 2005 & 2006 & 2007 & 2008 & 2009 \\
\hline $\begin{array}{l}\text { Number That Finished } \\
\quad \text { Integration Course }\end{array}$ & 31478 & 76401 & 67052 & 73557 & 70968 \\
$\begin{array}{l}\text { Number That Took } \\
\quad \text { Language Exam }\end{array}$ & 17482 & 50952 & 43853 & 78163 & 104387 \\
$\begin{array}{l}\text { Pass Rate among } \\
\quad \text { Test Participants (\%) }\end{array}$ & 69.5 & 71.8 & 67.4 & 47.9 & 45.2 \\
$\begin{array}{l}\text { Pass Rate among } \\
\text { Course Graduates }(\%)^{\mathrm{a}}\end{array}$ & 38.6 & 47.9 & 44.1 & 50.9 & 66.4 \\
\hline
\end{tabular}

SOURCE: BAMF 2010, 591.

${ }^{a}$ Percentages apply only to people who passed at the B1 level, as this is the required level for completing integration requirements for a permanent residence permit.

training and reaffirming the shift in authoritative barriers from citizenship to permanent residence. Formally, a consequence of not meeting the integration requirement is the refusal of a permanent residence permit. In practice, failure to complete the integration course only refeeds applicants back into the integration cycle: sitting for more exams and obtaining more language training until the $\mathrm{B} 1$ level is met, not to mention waiting longer to obtain permanent residence. Although immigrants who do not succeed enjoy a longer exposure to these programs of integration that, ultimately, improve their economic and social prospects in Germany, their access to permanent residence-hence, their political integration and security of status - is significantly delayed.

In contrast, the high pass rate for the citizenship test reflects this shift in decisive barriers. The citizenship test can ultimately be described as a symbolic and neutral addition of content to naturalization: it clearly does not make naturalization more difficult; nor does it decrease existing difficulty or add opportunities for acquisition. This diluted requirement is very much a product of its bargained origins, produced out of cross-party agreements and federal responses to statelevel anti-Muslim mobilization.

Through bargained restrictions and the expanded integration requirements for permanent residence, Germany is a case of intermediate restriction. Unlike Denmark, change was achieved through political maneuverings and in a deliberate strategy to offset liberalizing change. Center-right political actors, first in opposition and later in regional 
and federal government, offered counterbalancing then retrenching measures to maintain a comparatively restrictive citizenship. Resulting from these politics - both between insiders and outsiders and at different levels of government - the design and the implementation of civic requirements are more moderate than the Danish equivalent, although they still maintain the tone of restriction.

\section{The UK: Liberal Continuity with Attempted Moderation}

The attachment of integration requirements to naturalization and the promotion of newly defined "British values" have been described as part of a "quiet citizenship revolution." 77 In contrast to Germany and Denmark, whose national starting points was a restrictive form of citizenship reflecting insular, ethnocultural concepts of membership, the UK started with a liberal citizenship policy, reflecting an inchoate concept of the "British citizen" that remains unclear and is regularly redefined. ${ }^{78}$ Therefore, unlike restrictive regimes that use civic requirements to maintain restriction by decreasing acquisition of citizenship and promote integration at an alternative status, Britain uses civic requirements to maintain its liberal orientation (category 3), aiming to increase acquisition of citizenship and diminish the appeal of permanent residence. In many ways, the UK serves as a critical case for testing the "restrictive backlash" hypothesis. Even when restrictive political pressure was present, the ultimate abandonment of new restrictions is testament to the high price of change.

The UK has maintained a historically liberal set of citizenship policies, typified in low residence duration (five years), allowance for dual citizenship, and the conferring of citizenship through jus soli. English has been a formal requirement for citizenship since 1914, reaffirmed with the British Nationality Act of 1981 that the applicants demonstrate "sufficient knowledge of the English, Welsh or Scottish Gaelic language." But the practice of assessing language, as in Denmark and Germany, was always ad hoc, and successful completion of naturalization paperwork was often evidence of sufficiency. ${ }^{79}$ The 1981 Act was

${ }^{77}$ Kelly and Byrne 2007, 4.

${ }^{78}$ In a 2011 speech, Prime Minister David Cameron addressed the problem of Muslim extremism by noting that Britain shares accountability in that " $[\mathrm{w}] \mathrm{e}$ have failed to provide a vision of society to which they feel they want to belong." See also Cesarani 1996; Hampshire 2005.

${ }^{79}$ Also similar to early Danish and German practices, language requirements were not instruments of immigrant integration. Citizenship, according to Hansen 2000, was fashioned to preserve different categories of membership based on subjecthood (pp. 37-45). 
also the first time a definition of a British citizen formally appeared, and it was for the purpose of creating a distinction between British citizens and Commonwealth citizens.

The 2002 Nationality, Immigration and Asylum Act (NIA) was the major piece of legislation that not only strengthened the language requirement but also introduced "sufficient knowledge about life in the United Kingdom" and citizenship ceremonies. The assessment of language became standardized through the "Life in the UK" citizenship test, implemented in 2005. If applicants already had a sufficient level of English, they were subject to this twenty-four-question computerized test. If their English needed improvement, they could instead pursue a course-based route through the English Speakers of Other Languages (ESOL) "Skills for Life" curriculum and certification program for adult learners, whereby potential citizens learn English in the context of studying citizenship content. Finally, a citizenship ceremony was implemented in February 2004, where new citizens pledge to uphold British qua "democratic" values and swear an oath of allegiance to the monarchy.

One difference in the introduction of these membership requirements, in contrast to what is found in the rest of Europe, is that it occurred under a well-entrenched left government, insulated from significant opposition or veto players. With the exception of promigrant organizations, like the Joint Council for the Welfare of Immigrants, debates in the parliamentary houses opposing membership requirements largely focused on the content, such as what "life in the UK," British," and "sufficient" really mean, rather than on the measuring instruments themselves. And, as the exemplar of the single actor institutional system, the clear motivation for British policymakers in policy is winning over public opinion. Policy language is pervasive with references to keeping the public at the "heart of the changes" ${ }^{80}$ and "maintain[ing] public confidence." 81

A second difference is that in contrast to states where new requirements were born out of examining the immigrant integration problem, the UK began its new membership agenda not with immigrants but with British schools in mind. Following New Labour's 1997 landslide victory with Tony Blair at the helm, one of its first initiatives was introducing citizenship studies into the National Curriculum. This curriculum design was guided by Sir Bernard Crick, an academician who returned in an advisory role at the request of Home Secretary David

${ }^{80}$ Home Office 2008, 11.

${ }^{81}$ Home Office 2005, 6. 
Blunkett to extend "citizenship for schools" to "citizenship for immigrants" by way of promoting requirements for naturalization. ${ }^{82}$ The Life in the UK Advisory Board, consisting of Crick, ESOL teachers, and other experts, had a straightforward task: transitioning British citizenship from a bureaucratic process to a "significant life event" that is "meaningful and celebratory." 83 Where Germany and Denmark had tacit "guiding cultures," the UK had to deliberately create one through membership requirements and education. ${ }^{84}$

New integration requirements are specifically and explicitly designed to "incentivize" citizenship and encourage more people to acquire citizenship. ${ }^{85}$ Members of the Life in the UK Advisory Group initially cited a desire to "encourage people to apply for British citizenship at an earlier stage" in their residence because evidence showed flagging naturalization rates with prolonged residence. ${ }^{86}$ In terms of how this translated to Home Office goals directly, policymakers did not seek wholesale increases in naturalization rates per se. Rather, to quote Blunkett, it was to include value and skills for citizenship that would "promote the acceptable absorption of the uptake." 87

Following this priority to define membership in citizenship and promote a more meaningful naturalization process, the "knowledge of life and language" requirements were only later extended to the settlement stage (in 2007). This reflects the reality that-even after the "citizenship revolution"-immigrants may still not see incentives to naturalize but will nevertheless need to achieve integration as a permanent participant in the national polity. For example, in 2005, approximately 160,000 persons obtained citizenship while 180,000 obtained permanent residence. ${ }^{88}$ Derek McGhee even suggests that this new requirement marks the transition to a different phase in civic attitude, from David Blunkett's "model of civic assimilation" to Gordon Brown's broader "model of civic nationalism with its post-7/7 emphasis on loyalty, duty and responsibility." 89

This segues to a second strategy in policy-making for British mem-

${ }^{82}$ This extension was made in light of a new government report connecting language proficiency to social exclusion (Glover et al. 2001, 26). This report and subsequent policies were already under drafting and consideration before the Northern Riots and 9/11 would impel immigrant politics and integration back into the spotlight.

${ }_{83}$ Home Office 2003, 8.

${ }^{84}$ For more, see Asari, Halikiopoulou, and Mock 2008; and Meer and Modood 2008.

${ }^{85}$ See Kiwan 2008.

${ }^{86}$ Home Office 2003, 7

${ }^{87}$ Author interview with former home secretary David Blunkett, by phone, August 3, 2007.

${ }^{88}$ Philip Johnston, “Migrants Face New 'Britishness' Test.” Telegraph. December 5, 2006.

${ }^{89}$ McGhee 2009, 43. 
bership: moderating a liberal citizenship orientation by adding civic requirements in response to post-7/7 pressures for restriction (category 4). While ultimately a case of abandoned restriction and unfulfilled moderation of liberal citizenship, Britain demonstrates in this second phase of policy-making how civic requirements - in the presence of immigrant-related politics and under certain conditions-can modify or change a liberal citizenship orientation, just as new civic requirements can be used to modify restrictive positions. And, unlike liberal continuity, new civic restrictions are used to highlight - instead of diminish-differences between citizenship and permanent residence.

In 2009, the Labour government passed legislation that raised the residency duration from five to eight years and reconceptualized the progression from temporary residence to citizenship/permanent residence (the latter to be reserved only for those whose sending country does not grant dual citizenship), necessitating an interim stage of "probationary citizenship." One could exit this purgatory stage and get a reduction in residency through "active citizenship," which included participation in "community service," "improving command of English," "working hard and paying taxes," and "obeying the law." ${ }^{00}$ Part of this restriction resulted from drawing on the policy experiences of other, more restrictive countries, such as the Netherlands. ${ }^{91}$ But the central purpose of this new restriction was as a "vehicle for increasing public confidence' in immigration policy," ${ }^{\prime 2}$ namely, the introduction of a managed migration scheme (in the works since 2006).

In the comparative scope of civic requirements, and despite the clearly restrictive tone of these new requirements for permanent residence, there is some evidence to suggest that these additions were not designed to be entirely exclusionary. As Bernard Ryan points out, this policy was not intended to restrict access to citizenship per se but rather sought to "favour direct progression to British citizenship" as opposed to stopping incorporation at permanent residence. ${ }^{93}$ In other words, the requirement to "earn" citizenship may have incorporated new restrictions, but it did so to promote a decidedly inclusive objective. "Active citizenship" requirements would have added an extra burden to the process of naturalization, but in doing so it would have also lessened the new, considerably restrictive residency period (from eight to six years). Unlike in Denmark and Germany, the strategy was not to use require-

\footnotetext{
${ }^{90}$ Home Office 2008, 25.

${ }^{91}$ Kostakopoulou 2010, 834.

${ }^{92}$ McGhee 2009, 55.

${ }^{93}$ Ryan 2008, 289.
} 
ments to create an alternative and impediment to citizenship but to distinguish and add value to citizenship - in Gordon Brown's words, to create "enough of a distinction between those who want to reside here temporarily and those who want to become full British citizens." 4 This provides further evidence for the point that not all requirements in the "civic turn" are created equal: additions in restrictive settings can be quite different from additions in liberal ones. In the end, however, the Conservative-led coalition government decided against implementation of these new requirements, rejecting them not because public opinion had changed on immigration but because these Labour-led reforms were "too complicated, bureaucratic and, in the end, ineffective." ${ }^{55}$ While other cases, like the Netherlands, may be more typical of using civic requirements to add restrictive tones to citizenship, the British case highlights how political conditions can make this costly shift unfavorable.

Finally, turning to policy outcome and given the rejection of restrictive reforms, the practice of British civic integration policy maintains an overall liberal citizenship orientation. While the pass rate for the "Life in the UK" test for citizenship is low in comparison with other states (73 percent for 2011), this in fact reflects the maximally liberal and laissez-faire position of the state in administering integration, rather than the difficulty of the test, which individuals can prepare for by purchasing a study guide. Additionally, data show that new membership requirements do not play a significant role in driving down citizenship acquisition.

First, performance statistics alone do not define the comparative inclusiveness or exclusiveness of membership requirements; the design of the requirement-for example, involvement by the state and exemptions-plays an equally meaningful role. Thus, as mentioned in the German case, all migrants must meet the B1 level, even if they begin at the A1 level. They are first assessed on language by the course provider and then placed on the appropriate language track, completing language training until they reach B1. With this design, entry-level German speakers enjoy longer exposure to language training but are also kept in the system longer. The UK, by contrast, offers immigrants a choice: they can either complete the "Life in the UK" test (offered at the B1-equivalent level) or attend courses including language and civic content to proceed at their own pace, with the requirement that they

\footnotetext{
94 Brown 2008.

${ }^{95}$ May 2010.
} 
improve only one level, for example, from A1 to A2. In making this choice, immigrants in the UK self-assess their language ability. Here we see the UK as the exemplar liberal state in the more traditional sense of the word: it maintains maximal autonomy for the individual in determining his/her own route to integration by being minimally paternalist/statist, in that it defines only the benchmark of completion. As a result, approximately 80 percent of applicants fulfill their language and knowledge requirement by taking the test, ${ }^{96}$ presumably because it is less time consuming and cheaper, even if they may not be sufficiently prepared (that is, at the B1 proficiency level). In fact, the most typical reason for test failure is not confusing content but lack of language proficiency. ${ }^{97}$ This laissez-faire approach toward assessment, where the immigrant self-evaluates his or her ability to take the test, artificially inflates the fail rate for permanent residence and citizenship. The problem, then, of outcomes that look to be restrictive is not one of design — such as arbitrarily high language levels - but of erroneous individual self-assessment. In sum, while pass rates tell us much about the impact of requirements within a country, one should be careful about superficial interpretations or drawing direct comparisons across cases.

Second, where there is maximal flexibility in meeting the language and knowledge requirement in the UK, the effect on acquisition is ultimately low. As Table 5 reveals, on average, only a small percentage (2.7 in 2009) of applicants for citizenship are rejected annually for reasons of insufficient language or knowledge of life in the UK. Acquisition of citizenship actually doubled in the period between 2000 and 2007.98 Moreover, the pass rate is significantly higher, 82.2 percent, when the test is taken at the settlement stage. ${ }^{99}$ And recall that applicants for citizenship can, since 2007, fulfill their language and life in the UK requirement for settlement and have it "double count." The barrier of permanent residence requirements then is, therefore, not a real barrier at all.

In contrast to restrictive citizenship regimes that used integration requirements to decrease access to citizenship by way of permanent residence, the UK maintains a fluid, "joined up" system where the sta-

\footnotetext{
${ }^{96}$ Data obtained through Freedom of Information Act request. December 13, 2011. On file with author.

${ }^{97}$ BBC News 2010.

${ }^{98}$ Home Office 2010.

${ }^{99}$ Data obtained through Freedom of Information Act request. December 8, 2011. On file with author.
} 
TABLE 5

Reasons for Refusal of British Citizenship: Integration Requirements

\begin{tabular}{|c|c|c|c|c|c|c|c|c|}
\hline & 2002 & 2003 & 2004 & 2005 & 2006 & 2007 & 2008 & 2009 \\
\hline Oath Not Taken & 70 & 115 & 185 & 340 & 105 & 40 & 35 & 25 \\
\hline in Time & $(1 \%)$ & $(1.3 \%)$ & $(1.5 \%)$ & $(2.3 \%)$ & $(.7 \%)$ & $(.3 \%)$ & $(.4 \%)$ & $(2.7 \%)$ \\
\hline $\begin{array}{l}\text { Insufficient Knowl- } \\
\text { edge of English } \\
\text { and Knowledge } \\
\text { of Life in the UK } \\
\text { (KOL) }\end{array}$ & N/A & N/A & N/A & $\begin{array}{c}235 \\
(1.6 \%)\end{array}$ & $\begin{array}{c}500 \\
(3.7 \%)\end{array}$ & $\begin{array}{c}2365 \\
(16 \%)^{\mathrm{a}}\end{array}$ & $\begin{array}{c}610 \\
(6.9 \%)\end{array}$ & $\begin{array}{c}265 \\
(2.7 \%)\end{array}$ \\
\hline Total Refusals & 6925 & 8975 & 12120 & 14530 & 13610 & 14725 & 8735 & 9900 \\
\hline
\end{tabular}

SOURCE: Home Office 2010, 20.

${ }^{a}$ There are two, interrelated explanations for this outlier. First, English and KOL requirements were extended to acquiring Indefinite Leave to Remain (permanent residence) on April 2, 2007. Second, fees were raised this year at both stages: citizenship (from $£ 200$ to $£ 575$ ) [ $\$ 300$ to $\$ 886$ ] and permanent residence (from $£ 335$ to $£ 750$ ) [ $\$ 516$ to $\$ 1156$ ]. As permanent residence costs more, and the language and KOL requirements were now equal, significant demand for citizenship was generated among otherwise unprepared applicants. Additionally, a third reason that may have caused this aberrant percentage was the introduction of a revised test and handbook. After April 2, 2007, the KOL test was based on different material from the new handbook. Immigrants may not have obtained the new material and were therefore inadequately prepared for the exam.

tus of permanent residence is not a seen as a solution but instead is seen as the source of the problem. The challenge lies not in promoting permanent residence as an alternative but in creating the incentive for long-term residents to leave permanent residence and take up citizenship. This resulted in creating a compatibility of requirements and incentivizing citizenship with new content. The fact that Labor-designed restrictive policies to create a decisive path from temporary residence to citizenship were ultimately rejected-by a Conservative-led coalition no less-illustrates that the costs of policy change are high and citizenship has a weightiness to it that makes it difficult to change.

\section{Conclusion}

The civic integration experiences in Denmark, Germany, and the UK show that most-different states may have all made a turn toward obligatory integration, but they have done so for distinctly different reasons, under different conditions, and to different effect. Denmark shows how adoption in the absence of political opposition maintains restrictive membership postures. The UK tells a similar story of liberal continuity and adds important evidence against the restriction hypothesis, showing how the design of new membership requirements can 
perpetuate a traditionally liberal citizenship position. And Germany shows how under conditions of political contestation, objectives for liberalizing change are checked and new requirements perpetuate restriction, albeit in a more modest version than cases of unchallenged retrenchment. Highlighting differences in institutional start points and political experiences offers a dynamic explanation of membership requirements that - against existing approaches—depicts the "civic turn" as heterogeneous. Evidence from the interaction of policies and politics also suggests that we need to be cautious about making assertions about large-scale trends. By examining claims of convergence through detailed and nuanced case work, we get a very different picture about policy than we get from studies that claim national convergence by relying on vague dichotomies such as "obligations" and "rights." Methodological approaches that stay close to the ground can reveal much about the true nature of continuity and change.

Tracing these stories of adoption, design, and implementation confirm that new requirements do not signal departures from national approaches to citizenship, but rather fortify them. And short of a "lightening of citizenship" to shared liberal practices, ${ }^{100}$ a more appropriate description of this phenomenon might be anchoring citizenship in new content and rules. While a handful of states outside of Western Europe have recently adopted (Australia) or changed (Canada, Estonia, Israel, Latvia, United States) membership requirements (and the theoretical approach presented here can serve to interpret the significance and ultimate impact of this change), the empirical focus on Western Europe provides both sufficient similarity to test the crossnational convergence hypothesis and necessary diversity to test the "restrictive backlash" hypothesis. Moreover, the regional focus tells a unique story about traditional nation-states updating the content of belonging to acknowledge, if not always to accommodate, immigration and immigrant-related diversity as a fact of life. Instead of the "end of national models," the view across Europe shows states using new tools in variable ways to address national membership problems. If anything, new requirements show the truly adaptive and resilient nature of the nation-state in the twenty-first century. These new civic requirements indeed represent real innovation - articulating clear definitions for belonging and laying out arbitrary steps for outsiders to become insiders in principle, if not always in practice-while not fundamentally altering the parameters of what the state already has.

${ }^{100}$ Joppke 2010, 145-72. 
The short-term story of civic integration is one of fortifying citizenship, preserving national differences in state approaches to belonging by articulating concrete definitions of membership. However, a long-term view of policy change makes other alternatives possible. With more iterations of policy change over time, this could be the first juncture of a slow-moving process that changes the ultimate arrangement of state membership. As Theda Skocpol notes: "Policies transform or expand the capacities of the state. They therefore change the administrative possibilities for official initiatives in the future." ${ }^{101}$ For example, one of the real changes that comes with new requirements is bringing the state closer to the individual. Requirements secure a tighter relationship between the individual and the state; the state takes responsibility for ensuring integration while the individual is directly accountable to the state at increased stages of interaction. Giving the state a more prominent role in the lives of newcomers and pulling the immigrant ever closer to the state sets a precedent for a bevy of potential illiberal possibilities - ranging from surveillance to the conditionality of rights. Mandatory integration has already been discussed as an instance of "illiberal liberalism," but these serious extremes may be unintended outcomes of a causal chain that begins here. Indeed, a feature of historical institutionalism is the possibility that long-term outcomes are often "by-products of social processes rather than embodying the goals of social actors." 102 While, for the time being, membership requirements promote integration and reaffirm national approaches to citizenship, it is possible that this may be the first step of the adaptive state to altering not only the orientation of citizenship but the citizen-state relationship altogether.

\section{REFERENCES}

Asari, Eva-Maria, Daphne Halikiopoulou, and Steven Mock. 2008. "British National Identity and the Dilemmas of Multiculturalism." Nationalism and Ethnic Politics 14, no. 1: 1-28.

BAMF. 2010. Bericht der Beauftragten der Bundesregierung für Migration, Flüchtlinge und Integration über die Lage der Ausländerinnen und Ausländer in Deutschland. Berlin, Germany: BAMF (Die Beauftragte der Bundesregierung für Migration, Flüchtlinge und Integration).

BBC News. 2010. "British Citizenship Test: One in Three Immigrants Fails." At http://news.bbc.co.uk/2/hi/8707152.stm, accessed December 28, 2011.

Bauböck, Rainer, and Christian Joppke, eds. 2010. How Liberal Are Citizenship Tests? Edited by E. C. Observatory, vol. 2010/41. Florence, Italy: Robert Schuman Centre for Advanced Studies, EUI.

${ }^{101}$ Cited in Pierson 1993, 603.

102 Pierson 2004, 15 
Böcker, Anita, and Tineke Strik. 2011. "Language and Knowledge Tests for Permanent Residence Rights: Help or Hindrance for Integration?” European Journal of Migration and Law 13: 157-84.

Brown, Gordon. 2008. Speech on Managed Migration and Earned Citizenship. At pm.gov.uk., accessed February 28, 2008.

Brubaker, Rogers. 1992. Citizenship and Nationhood in France and Germany. Cambridge, Mass.: Harvard University Press.

- 2001. "Return of Assimilation? Changing Perspectives on Immigration and Its Sequels in France, Germany, and the United States." Ethnic and Racial Studies 24, no. 4: 531-48.

Buley, Jennifer. 2012. “GovernmentProposes End to 'Points System.'” The Copenhagen Post. At http://www.cphpost.dk/news/making-cut-immigration-dk/govern ment-proposes-end-\%25E2\%2580\%2598points-system\%25E2\%2580\%2599, accessed January 3, 2012.

Cameron, David. 2011. Speech at the Munich Security Conference. At http:// www.number10.gov.uk/news/pms-speech-at-munich-security-conference/, accessed March 27, 2012.

Castles, Stephen, and Mark J. Miller. 2003. The Age of Migration. Basingstoke, UK: Palgrave Macmillan.

Cesarani, David. 1996. "The Changing Character of Citizenship and Nationality in Britain." In D. Cesarani and M. Fulbrook, eds., Citizenship, Nationality and Migration in Europe. London, UK: Routledge.

Common European Framework of Reference for Languages (CEFR). 2001. The Common European Framework of Reference for Language: Learning, Teaching, Assessment. Cambridge, UK: Cambridge University Press.

Cornelius, Wayne, Takeyuki Tsuda, Philip Martin, and James Hollifield, eds. 2004. Controlling Immigration: A Global Perspective, 2nd ed. Stanford, Calif.: Stanford University Press.

de Groot, Gerard-Rene, Jan-Jaap Kuipers, and Franziska Weber. 2009. “Passing Citizenship Tests as a Requirement for Naturalisation: A Comparative Perspective." In E. Guild, K. Groenendijk, and S. Carrera, eds., Illiberal Liberal States: Immigration, Citizenship and Integration in the EU. Farnham, Surrey: Ashgate.

Ersbøll, Eva. 2010. "On Trial in Denmark." In R. van Oers, E. Ersbøll and D. Kostakopoulou, eds., A Re-definition of Belonging? Language and Integration Tests in Europe. Leiden, Netherlands: Martinus Nijhoff.

Ersbøll, Eva, and Laura Katrine Gravesen. 2010. “Country Report Denmark.” In The INTEC Project: Integration and Naturalisation Tests: The New Way to European Citizenship. Nijmegen, Netherlands: Centre for Migration Law, Radboud University.

Etzioni, Amitai. 2011. "Citizenship in a Communitarian Perspective." Ethnicities 11, no. 3: 336-49.

Glover, Stephen, Ceri Gott, Anais Loizillon, Jonathan Portes, Richard Price, Sarah Spencer, Vasanthi Srinivasan, and Carole Willis. 2001. "Migration: An Economic and Social Analysis." In RDS Occasional Paper no. 67. London, UK: Home Office.

Goodman, Sara Wallace. 2010a. "Integration Requirements for Integration's Sake? Identifying, Categorising and Comparing Civic Integration Policies.” Journal of Ethnic and Migration Studies 36, no. 5: 753-72.

- 2010b. "Naturalisation Policies in Europe: Exploring Patterns of Inclu- 
sion and Exclusion." In EUDO Citizenship Comparative Reports. Florence, Italy: EUDo Citizenship, Robert Schuman Centre for Advanced Studies, EUI.

. 2011. "Controlling Immigration through Language and Country Knowledge Requirements.” West European Politics 34, no. 2: 235-55.

Goodman, Sara Wallace, and Marc Morjé Howard. 2011. "Evaluating and Explaining the Restrictive Backlash in Citizenship Policy in Europe." Paper presented at UC Berkeley Institute of Government Studies and the UC European Union Center of Excellence conference on The Political Incorporation of Immigrants: Progress, Prospects, and Pitfalls in Europe and North America, Berkeley, Calif., March 4-5.

Green, Simon. 2012. "Much Ado about Not-Very-Much? Assessing Ten Years of German Citizenship Reform.” Citizenship Studies 16, no. 2: 173-88.

Guild, Elspeth, Kees Groenendijk, and Sergio Carrera, eds. 2009. Illiberal Liberal States: Immigration, Citizenship, and Integration in the EU. Farnham, Surrey; Burlington, Vt.: Ashgate.

Hall, Peter A. 1986. Governing the Economy: The Politics of State Intervention in Britain and France. Oxford, UK: Oxford University Press.

Hampshire, James. 2005. Citizenship and Belonging: Immigration and the Politics of Demographic Governance in Post-War Britain. Houndmills, Balsingstoke, Hampshire: Palgrave.

Hansen, Randall. 2000. Citizenship and Immigration in Post-War Britain : The Institutional Origins of a Multicultural Nation. Oxford, UK, and New York, N.Y.: Oxford University Press.

-2008a. "A New Citizenship Bargain for the Age of Mobility? Citizenship Requirements in Europe and North America." Washington, D.C.: Migration Policy Institute.

- 2008b. "The Poverty of Postnationalism: Citizenship, Immigration, and the New Europe." Theory and Society 38, no. 1: 1-24.

Hansen, Randall, and Patrick Weil, eds. 2001. Towards a European Nationality: Citizenship, Immigration and Nationality Law in the EU. London, UK: Palgrave-Macmillan.

Hartnell, Helen Elizabeth. 2006. "Belonging: Citizenship and Migration in the European Union and in Germany." Berkeley Journal of International Law 24, no. 1: 330-400.

Home Office, ed. 2003. "The New and the Old: The Report of the 'Life in the United Kingdom' Advisory Group.” London, UK: Home Office.

—. 2005. "Controlling Our Borders: Making Migration Work for Britain." London, UK: TSO.

2008. "The Path to Citizenship: Next Steps in Reforming the Immigration System.” London, UK: Border and Immigration Agency Communications Directorate.

- 2010. "Home Office Statistical Bulletin: British Citizenship Statistics, United Kingdom 2009.” London, UK: Home Office.

Howard, Marc Morjé. 2009. The Politics of Citizenship in Europe. Cambridge, UK: Cambridge University Press.

- 2010. "The Impact of the Far Right on Citizenship Policy in Europe: Explaining Continuity and Change." Journal of Ethnic and Racial Studies 35, no. 5: 735-51.

Jacobs, Dirk, and Andrea Rea. 2007. “The End of National Models? Integration 
Courses and Citizenship Trajectories in Europe." Paper presented at the annual meeting of the European Union Studies Association, Montréal, Quebec, Canada, May 17-19.

Jacobson, David. 1997. Rights across Borders: Immigration and the Decline of Citizenship. Baltimore, Md.: Johns Hopkins University Press.

Janoski, Thomas. 2010. The Ironies of Citizenship: Naturalization and Integration in Industrialized Countries. Cambridge, UK: Cambridge University Press.

Joppke, Christian. 1999. Immigration and the Nation-State: The United States, Germany, and Great Britain. Oxford, UK, and New York, N.Y.: Oxford University Press.

- 2003. "Citizenship between De- and Re-Ethnicization." European Journal of Sociology 44, no. 3: 429-58.

. 2004. "The Retreat of Multiculturalism in the Liberal State: Theory and Policy." British Journal of Sociology 55, no. 2: 237-57.

—. 2007a. "Beyond National Models: Civic Integration Policies for Immigrants in Western Europe.” West European Politics 30, no. 1: 1-22.

- 2007b. "Transformation of Immigrant Integration: Civic Integration and Antidiscrimination in the Netherlands, France, and Germany." World Politics 59, no. 2 (January): 243-73.

- 2008. "Comparative Citizenship: A Restrictive Turn in Europe?" Law and Ethics of Human Rights 2, no. 1: 1-41.

. 2010. Citizenship and Immigration. Cambridge, UK, and Malden, Mass.: Polity.

Joppke, Christian, and Ewa T. Morawska. 2003. Toward Assimilation and Citizenship: Immigrants in Liberal Nation-States. Houndmills, Basingstoke, Hampshire: Palgrave-Macmillan.

Kelly, Ruth, and Liam Byrne. 2007. "A Common Place.” London, UK: Fabian Society.

Kiwan, Dina. 2008. "A Journey to Citizenship in the United Kingdom." International Journal on Multicultural Societies 10, no. 1: 60-75.

Koopmans, Ruud, Ines Michalowski, and Stine Waibel. 2012. "Citizenship Rights for Immigrants: National Political Processes and Cross-National Convergence in Western Europe, 1980-2008." American Journal of Sociology 117, no. 4: 1202-45.

Koopmans, Ruud, Paul Statham, Marco Giugni, and Florence Passy. 2005. Contested Citizenship: Immigration and Cultural Diversity in Europe. Minneapolis, Minn.: University of Minnesota Press.

Kostakopoulou, Dora. 2010a. "Matters of Control: Integration Tests, Naturalisation Reform and Probationary Citizenship in the United Kingdom." Journal of Ethnic and Migration Studies 36, no. 5: 829-46.

. 2010b. "The Anatomy of Civic Integration." Modern Law Review 73, no. 6: 933-58.

Kymlicka, Will. 2010. "The Rise and Fall of Multiculturalism? New Debates on Inclusion and Accommodation in Diverse Societies." International Social Science Journal 61, no. 199: 97-112.

May, Theresa. 2010. "Speech by Home Secretary." November 5.

McGhee, Derek. 2009. "The Paths to Citizenship: A Critical Examination of Immigration Policy in Britain since 2001." Patterns of Prejudice 43, no. 1: 41-64.

Meer, Nasar, and Tariq Modood. 2008. "The Multicultural State We're In: Mus- 
lims, 'Multiculture' and the 'Civic Re-balancing' of British Multiculturalism.” Political Studies 57, no. 3: 473-97.

Michalowski, Ines. 2010. "Integration Tests in Germany: A Communitarian Approach?” In R. van Oers, E. Ersbøll, and D. Kostakopoulou, eds., $A R e-$ definition of Belonging? Language and Integration Tests in Europe. Leiden, Netherlands: Martinus Nijhoff.

Ministry of Justice (Netherlands), ed. 1998. "Wet Inburgering Nieuwkomers (Newcomers Integration Act).” The Hague, Netherlands: Ministry of Justice.

Ministry of Refugee, Immigration and Integration Affairs (Denmark). 2011. At http://www.nyidanmark.dk, accesssed August 10, 2011.

Mouritsen, Per. 2006. "The Particular Universalism of a Nordic Civic Nation: Common Values, State Religion and Islam in Danish Political Culture." In T. Modood, A. Triandafyllidou, and R. Zapata-Barrero, eds., Multiculturalism, Muslims and Citizenship: A European Approach. London, UK: Routledge.

—. 2011. "Beyond Post-national Citizenship: Access, Consequence, Conditionality." In A. Triandafyllidou, T. Modood, and N. Meer, eds., European Multiculturalisms. Edinburgh, Scotland: Edinburgh University Press.

Mouritsen, Per, and Tore Vincents Olsen. 2011 (online) and forthcoming (in print). "Denmark between Liberalism and Nationalism." Ethnic and Racial Studies. First Article: 1-20.

MPG. 2011. "The Migrant Integration Policy Index (MIPEX).” Migration Policy Group and British Council.

Müller, Jan-Werner. 2007. "Is Europe Converging on Constitutional Patriotism? (And If So: Is It Justified?)." Critical Review of International Social and Political Philosophy 10, no. 3: 377-87.

OECD. 2003. "International Migration Outlook (SOPEMI)." At www.oecd.org/ migration, accessed August 5, 2011.

_. 2010. "International Migration Outlook (sopemi)." At www.oecd.org/ migration, accessed August 5, 2011.

Oers, Ricky van, Eva Ersbøll, and Theodora Kostakopoulou. 2010. A Re-definition of Belonging? Language and Integration Tests in Europe. Leiden, Netherlands: Martinus Nijhoff Publishers.

Orgad, Liav. 2010. "Illiberal Liberalism: Cultural Restrictions on Migration and Access to Citizenship in Europe." American Journal of Comparative Law 58, no. 1: 53-106.

Pascouau, Yves. 2010. "Integration Measures in France: An Evolving Process between Integration and Migration Issues.” In Ricky van Oers, Eva Ersbøll, and Theodora Kostakopoulou, eds., A Re-definition of Belonging? Language and Integration Tests in Europe. Leiden, Netherlands: Martinus Nijhoff Publishers.

Pierson, Paul, 1993. "When Effect Becomes Cause: Policy Feeback and Political Change." World Politics 45, no. 4 (July): 595-628.

- 2004. Politics in Time. Princeton, N.J.: Princeton University Press.

Reeskens, Tim, and Marc Hooghe. 2010. "Beyond the Civic-Ethnic Dichotomy: Investigating the Structure of Citizenship Concepts across Thirty-three Countries." Nations and Nationalism 16, no. 4: 579-97.

Ryan, Bernard. 2008. "Integration Requirements: A New Model in Migration Law." Journal of Immigration Asylum and Nationality Law 22, no. 4: 303-16.

Sassen, Saskia. 1998. “The De Facto Transnationalizing of Immigration Policy.” 
In Christian Joppke, ed., Challenge to the Nation-State: Immigration in Western Europe and the United States. Oxford, UK: Oxford University Press.

Schain, Martin. 2008. The Politics of Immigration in France, Britain, and the United States: A Comparative Study. New York, N.Y.: Palgrave-Macmillan.

Schönwälder, Karen, and Triadafilos Triadafilopoulos. 2012. "A Bridge or Barrier to Incorporation? Germany's 1999 Citizenship Reform in Critical Perspective." German Politics and Society 30, no. 1: 52-70.

Seveker, Marina, and Anne Walter. 2010. "Country Report Germany." In The INTEC Project: Integration and Naturalisation Tests: The New Way to European Citizenship. Nijmegen, Netherlands: Centre for Migration Law, Radboud University.

Smith, Rogers. 2001. “Citizenship: Political.” In N. J. Smelser and P. Baltes, eds., International Encyclopedia of the Social and Behavioral Sciences. New York, N.Y.: Pergamon.

Soysal, Yasemin Nuhoğlu. 1994. Limits of Citizenship: Migrants and Postnational Membership in Europe. Chicago, Ill.: University of Chicago.

Spiegel Online. 2009. "Who Wants a Passport? Miniscule Fail Rate for German Citizenship Test." At http:/www.spiegel.de/international/germany/ 0,1518,599131,00.html.

Spiro, Peter J. 2008. Beyond Citizenship: American Identity after Globalization. Oxford, UK: Oxford University Press.

Strik, Tineke, Maaike Luiten, and Ricky van Oers. 2010. "Country Report The Netherlands." In The INTEC Project: Integration and Naturalisation Tests: The New Way to European Citizenship. Nijmegen, Netherlands: Centre for Migration Law, Radboud University.

Thelen, Kathleen Ann, and Sven Steinmo. 1992. "Historical Institutionalism in Comparative Politics." In Sven Steinmo, Kathleen A. Thelen, and Frank Longstreth, eds., Structuring Politics: Historical Institutionalism in Comparative Analysis. Cambridge, UK: Cambridge University Press.

Tilly, Charles. 1997. "A Primer on Citizenship." Theory and Society 26, no. 4: 599-602.

Triadafilopoulos, Phil. 2011. "Illiberal Means to Liberal Ends? Understanding Recent Immigrant Integration Policies in Europe." Journal of Ethnic and Migration Studies 37, no. 6: 861-80.

van Oers, Ricky. 2010. "Citizenship Tests in the Netherlands, Germany and the UK." In Ricky van Oers, Eva Ersbøll, and Theodora Kostakopoulou, eds., $A$ $R e$-definition of Belonging? Language and Integration Tests in Europe. Leiden, Netherlands: Martinus Nijhoff Publishers.

Vink, Maarten P., and Gerard-Rene de Groot. 2010. "Birthright Citizenship: Trends and Regulations in Europe." In EUDO Citizenship Comparative Reports. Florence, Italy: EUDO Citizenship, Robert Schuman Centre for Advanced Studies, EUI.

Wright, Sue, ed. 2008. "Special Issue: Citizenship Tests in a Post-National Era." IJMS: International Journal on Multicultural Societies 10, no. 1. 